\title{
The Bosnian Chardaklia House in the Cuhovici Village Near the Konjic
}

\author{
Ahmet Hadrović \\ Faculty of Architecture, University of Sarajevo, Sarajevo, Bosnia and Herzegovina \\ Email address: \\ hadrovic.ahmet@gmail.com, ahmet.hadrovic@af.unsa.ba \\ To cite this article: \\ Ahmet Hadrović. The Bosnian Chardaklia House in the Cuhovici Village Near the Konjic. International Journal of Architecture, Arts and \\ Applications. Vol. 7, No. 2, 2021, pp. 45-55. doi: 10.11648/j.ijaaa.20210702.13
}

Received: May 20, 2021; Accepted: June 1, 2021; Published: June 9, 2021

\begin{abstract}
Bosnia and Herzegovina has a wide range of architectural programs of traditional architecture which, according to its concept, design and materialization has the characteristics of bioclimatic architecture: houses (main and auxiliaryseasonal), barns, utilitarian architecture (mills, handicrafts), sacral (mosques), turbe, church). The Bosnian Housechardaklija is one of the most authentic achievements of traditional architecture in Bosnia and Herzegovina. As a residential building, it most fully reflects the housing culture of the Bosnian-Herzegovinian man, and his overall view of the world. The Bosnian House-chardaklia reached its classical stage of development in the 18th century, and the solutions reached will be maintained during the 19th and 20th centuries, in some places until today. Unlike the City House (which in Bosnia and Herzegovina, similarly elsewhere in the world, was generated with more or less pronounced influences of other cultures), the Bosnian House-chardaklia directly reflects the natural environment of Bosnia and Herzegovina and the social environment, socio-economic relations, philosophy, religion, morals...). Bosnia and Herzegovina is rich in forests and building stone of various performances, from stone suitable for masonry, stone suitable for floor coverings to stone slabs suitable for roofing. This fact is directly reflected in the generation of the spatial concept of the house, its construction and materialization. The presented examples of the Bosnian House-chardaklia in Cuhovici near Konjic keep the basic concept of the developed type of this house, but in their architectural-spatial concept it is more modest (rooms are smaller, there is no sofa), which is a direct consequence of colder climate and domination of stone over wood material.
\end{abstract}

Keywords: Bosnian House-chardaklia, Traditional Architecture, Wood, Stone, Cukas Family, Tresnjo Family

\section{Introduction}

Folk (traditional) architecture is the most direct way of expressing the misery of the natural and social environment, on the one hand, and man (the wide array of his being), on the other $[1,13,15]$. Therefore, this architecture shows so much specificity according to the spatial-geographical and climatic characteristics of a place and the social environment in which people live [2, 8-11]. However, unlike authorial architecture (mainly in cities) [10], traditional architecture preserves its achieved typology, design and materialization over a long period of time, while remaining inert to the more or less dynamic social environment of the wider community

\section{$[3-7,12,13]$.}

This paper presents two houses in the village of Cuhovici (Figure 1). The house of the Tresnjo family is still the same as it was when it was built (at the beginning of the 20th century), and it still lives in the way of life at the time of its construction [1]. The house of the Cukas family was built at the same time as the house of the Tresnjo family, but it has undergone certain adaptations, in accordance with the needs of modern man.

The presentation of the Bosnian House-chardaklia in Cuhovici is a contribution to the consideration of major topics of architecture: "architecture in context", "architecture as a frame of life", "architecture as an energy system" [14], "bioclimatic architecture" [1]... 

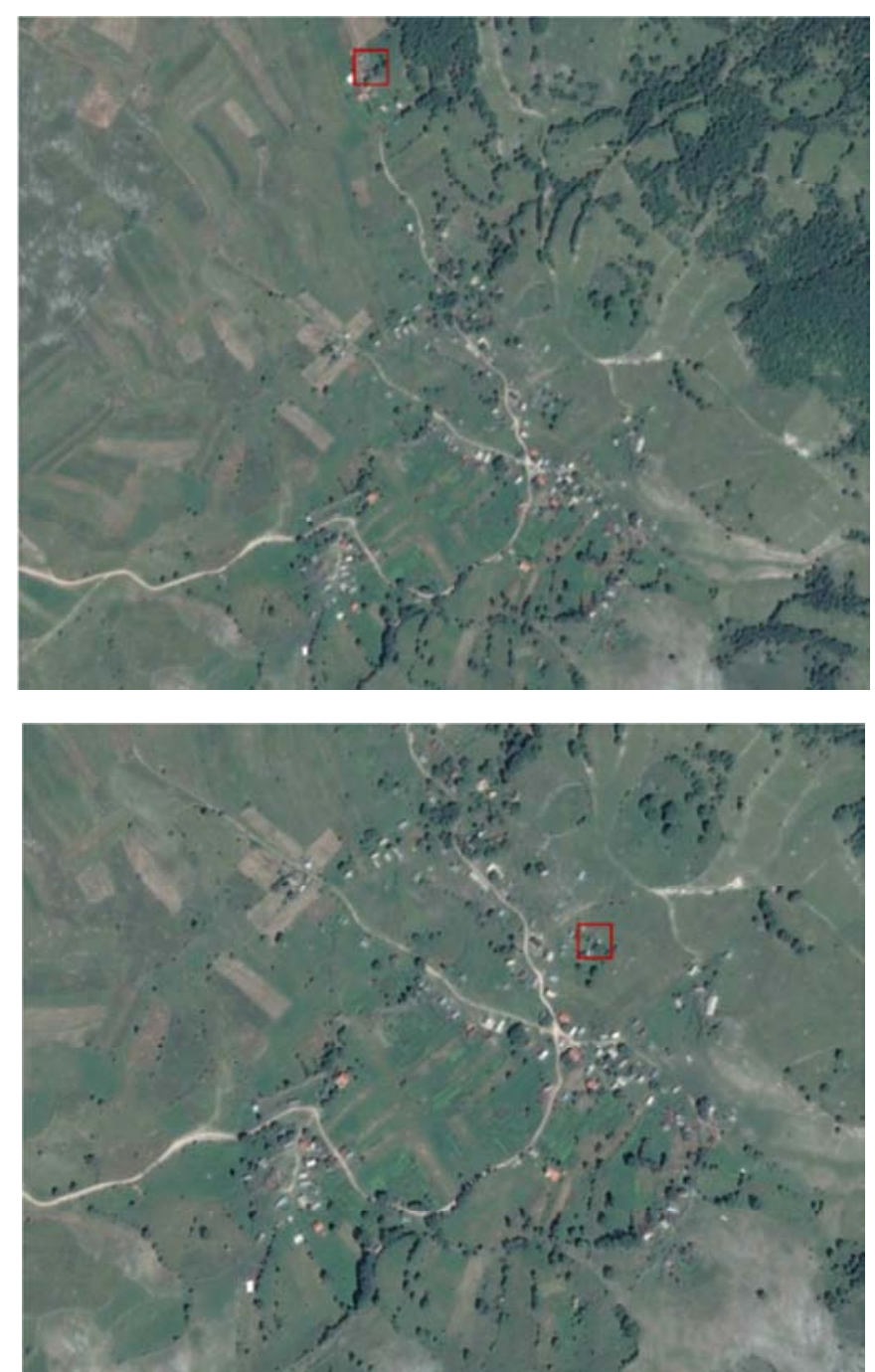

Figure 1. Left: Trešnjo family house in Cuhovici near Konjic. Location (Geographic coordinates: $43^{\circ} 38^{\prime} 42.52^{\prime \prime} N$; $18^{\circ} 08^{\prime} 18.59^{\prime \prime}$ E; Elevation: $1361 \mathrm{~m}$.

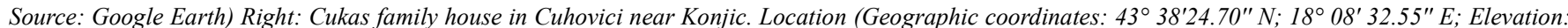
1359 m. Source: Google Earth, Accessed: 02/18/2020.).

\section{Spatial-shape Characteristics of a Home}

The houses of the Tresnjo family and the Cukas family in Cuhovici are almost identical (Figures 2 and 3). Each of them was placed on sloping terrain with southern exposure (which is almost the rule for the Bosnian house chardaklija) allowing the usual disposition of the horizontal and vertical plan of the house [15]. Each of them has a basement below the ground floor, ground floor and first floor "čardakmeđurogovima" ("chardak among the horns"). On the ground floor level are the main rooms of the house: the living room ("kuca") with an open hearth and the main room, above the basement. The space of the "kuca" is open to the roof so that smoke from the hearth can flow freely towards the roof (Figures 2, 4, 5) [14]. This is crucial for the timber structure of the roof and the (original) timber roof covering, since the smoke prevents the insects from affecting the timber structure and the cover. In addition, the tar contained in the smoke impregnates the timber of the structure and cover and thus makes it resistant to moisture rot. At the level of the floor there is a "čardakmeđurogovima" ("chardak among the horns"). At the home of the Tresnjo family, chardak is used as a place for drying meat and cheese and as a pantry for some food products. At the Cukas family's home, the space between the open hearth and the attic is largely closed, and smoke from the hearth only brooms in the narrower part. This is the result of an adaptation of the building when the space of the chardak was transformed into an independent space (of another owner) with a newly developed standalone approach (Figure 2). Over time, the wooden cover in the house of the Tresnjo family was replaced by the cover of galvanized sheet metal, and at the house of the Cukas family by the cover of corrugated laminate boards (Figure 3).

Both houses offer sweeping views of the village and further up Prenj-mountain 1 .

1The author visited these houses on 13.08.2016. Information about the house and about the Tresnjo family was provided by Mrs. Raha (born Bandic) Tresnjo (1937), the wife of the homeowner, Mr. Hamid (Zejnil) Tresnjo. 

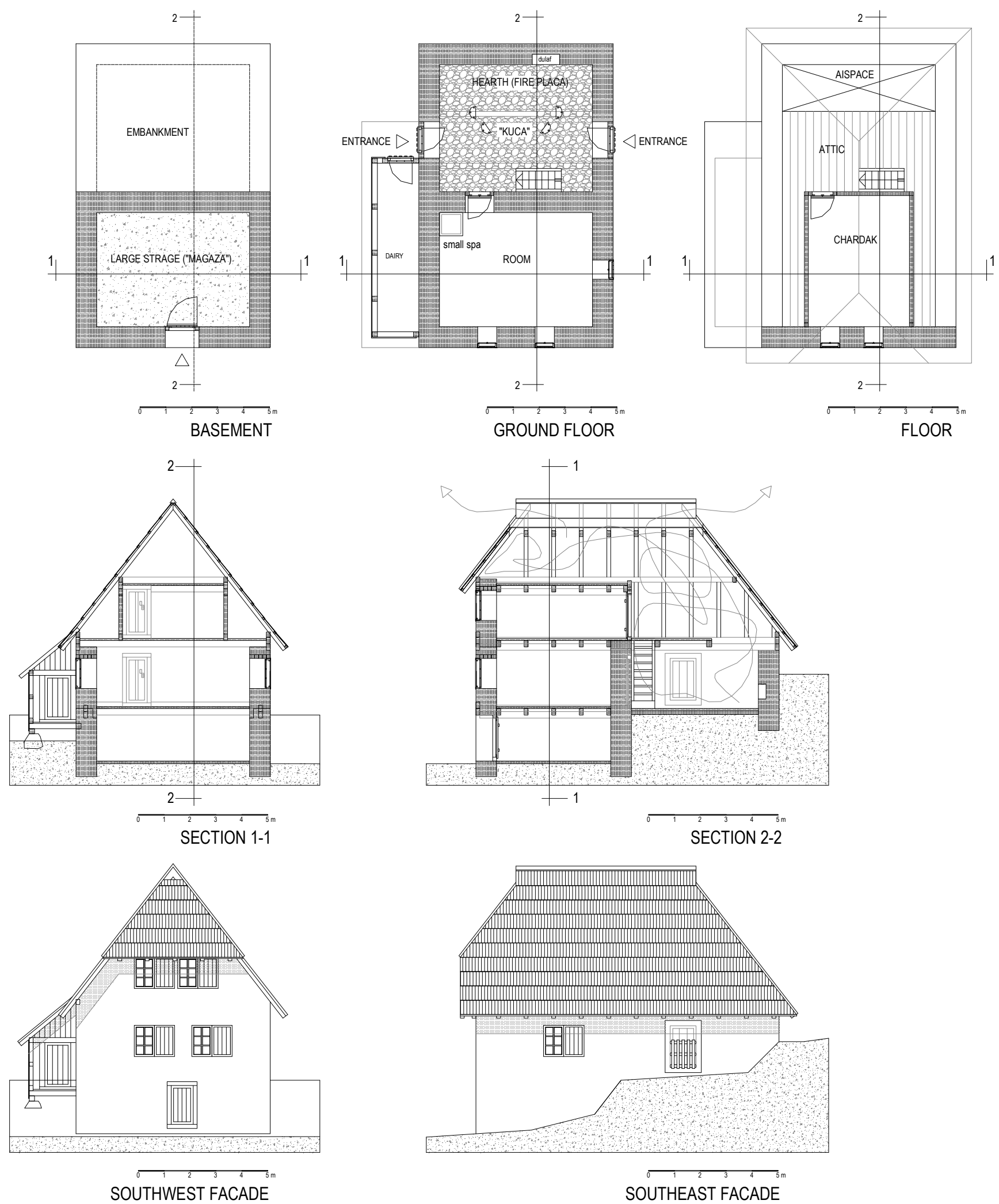

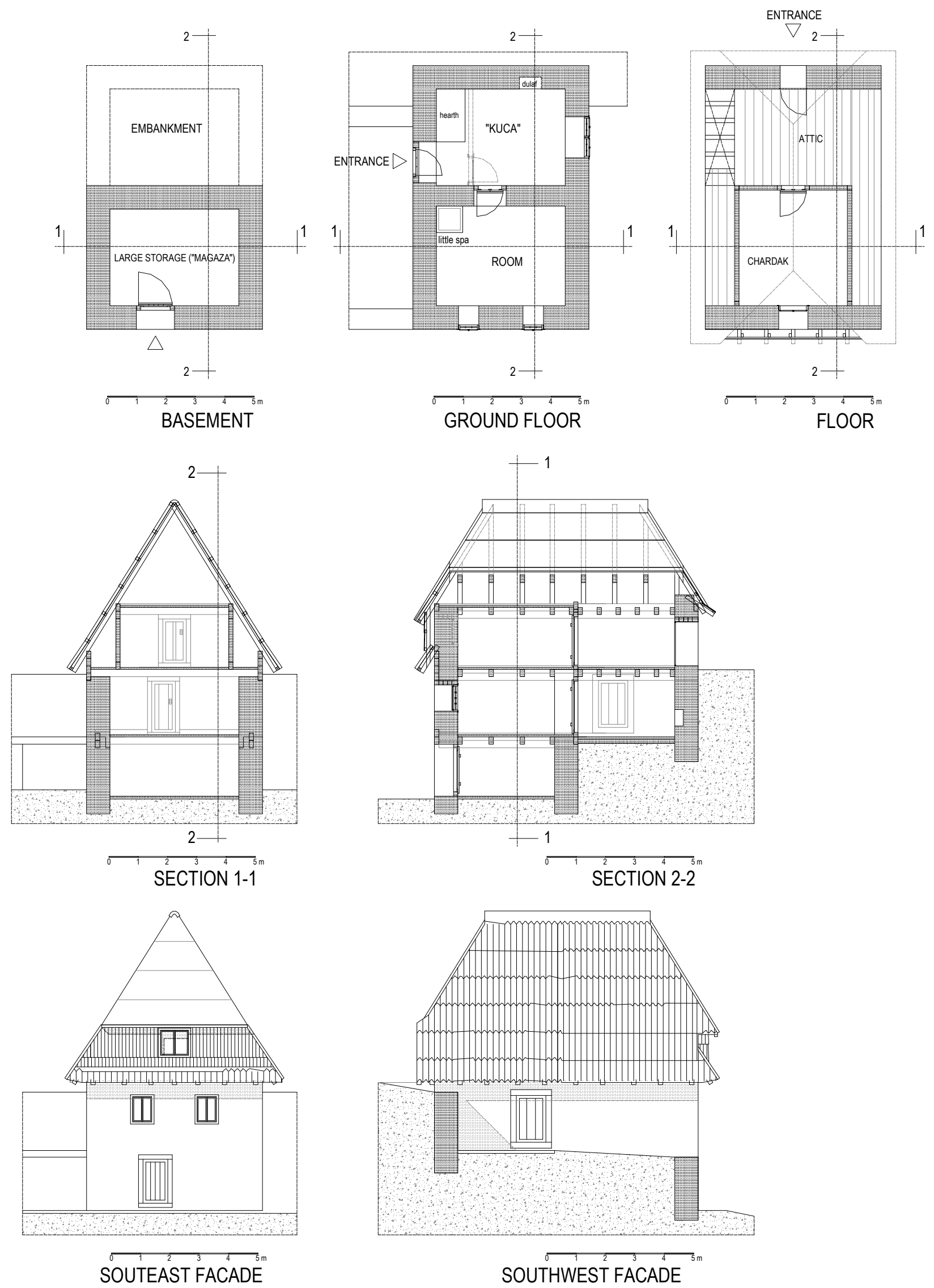

Figure 2. Houses of Tresnjo (left) and Cukas family (right). Drawings: Prof. Ahmet Hadovic (2016). 


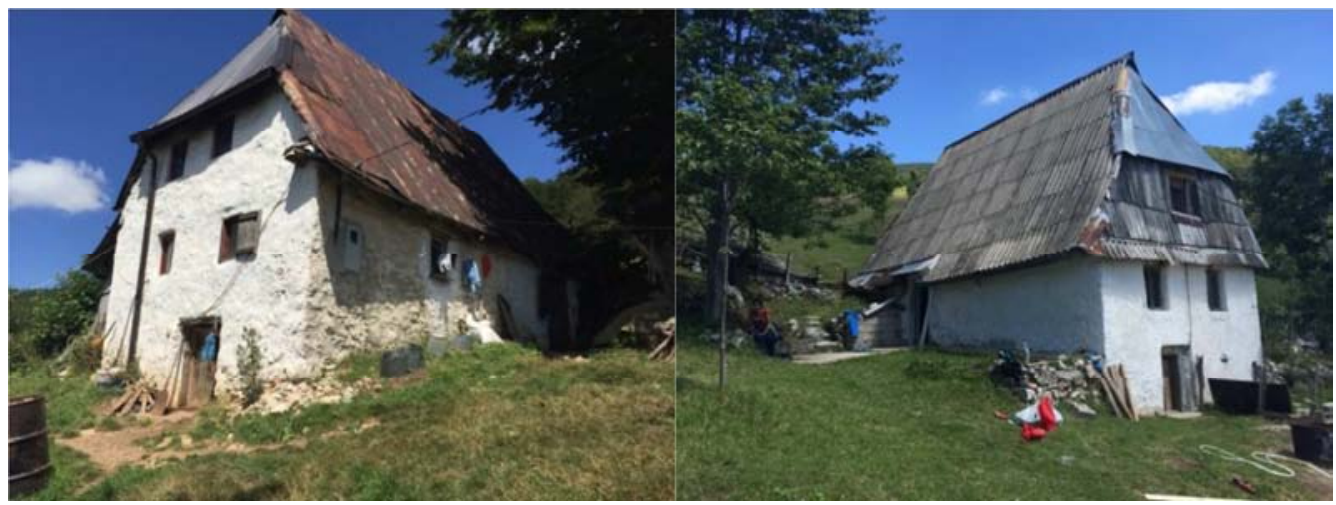

Photos: Prof. Ahmet Hadrović (08/13/2016.)

Figure 3. Tresnjo family house in Cuhovici near Konjic (left) and Cukas family house (right).

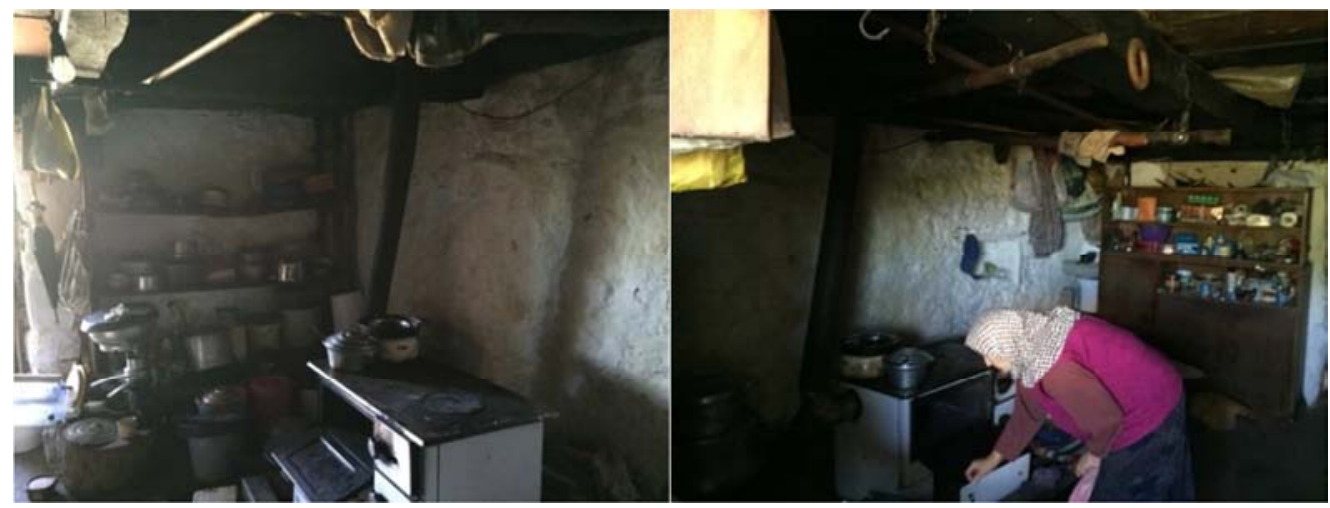

Figure 4. Space of "kuca"(Tresnjo family house).
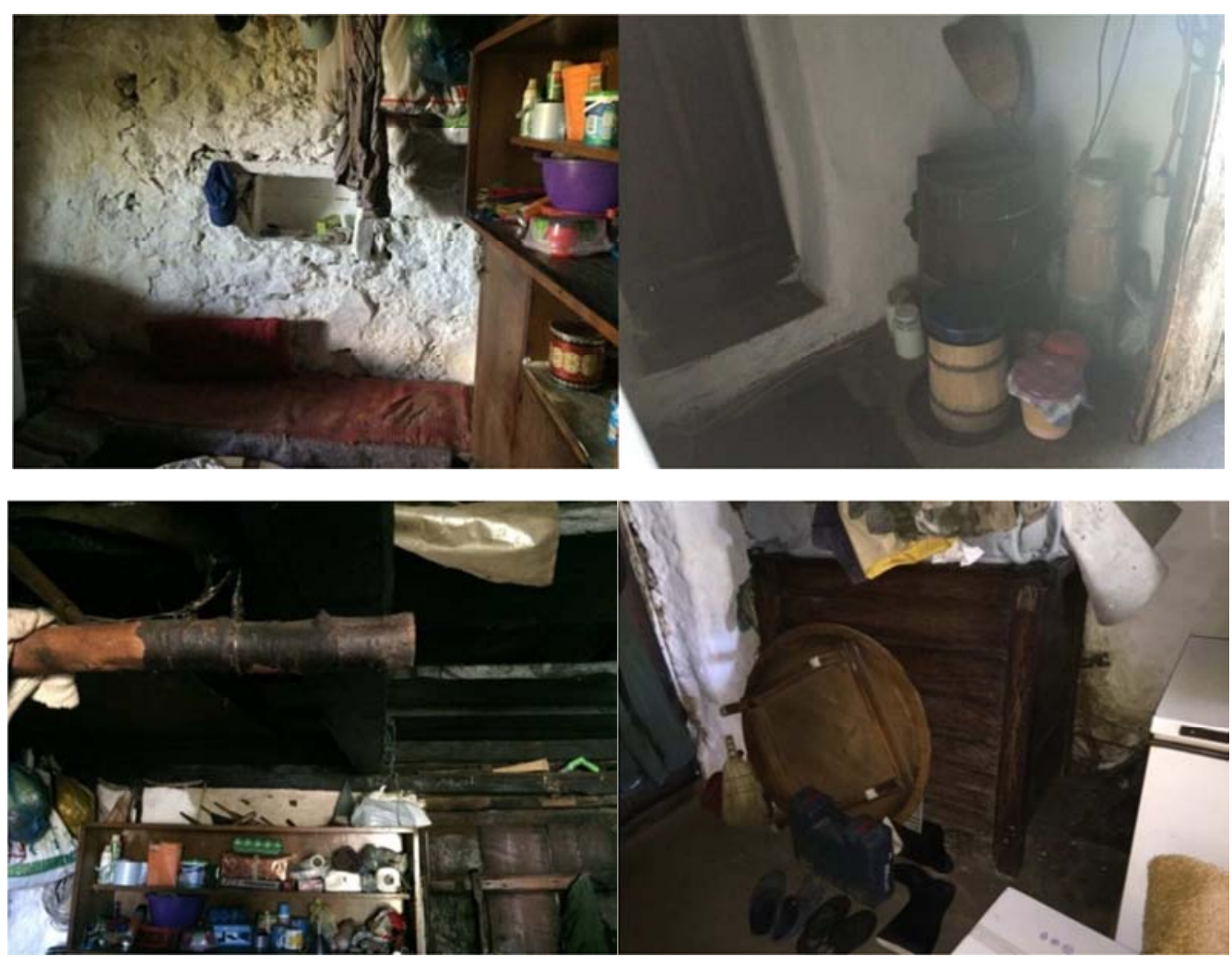

Figure 5. Elements of equipment in the "kuca" space: a wooden crate (locally called a "hambar" ("barn") for storing flour, a low wooden dining table (blue, sofa). 


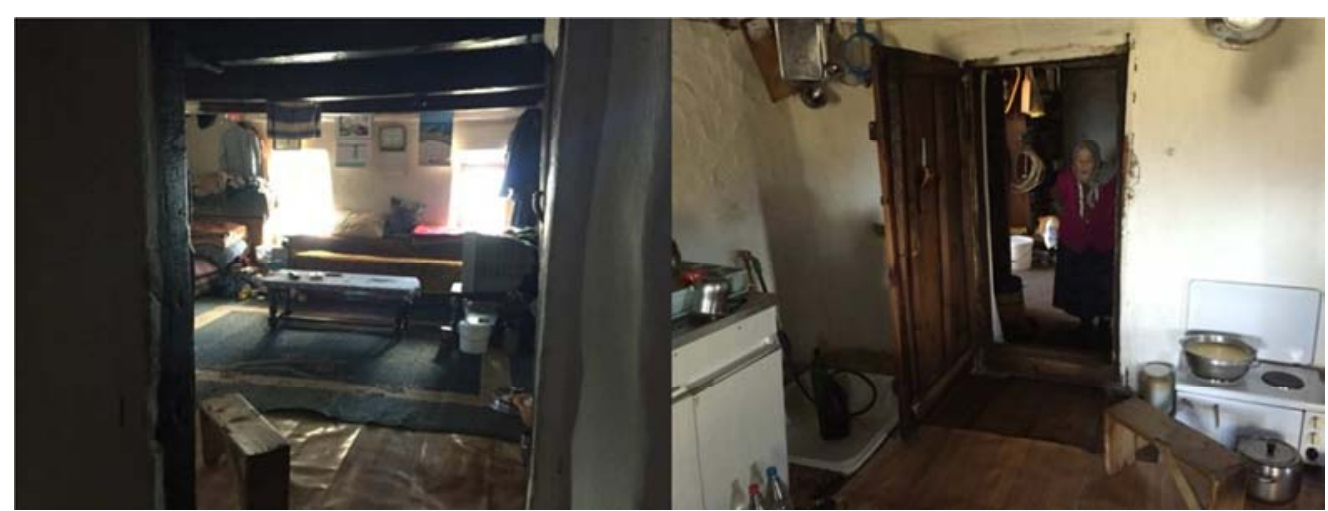

Figure 6. View from the "kuca" to the room through the open door (left) and view from the room to the "kuća"through the open door (right) in the house of the Tresnjo family.
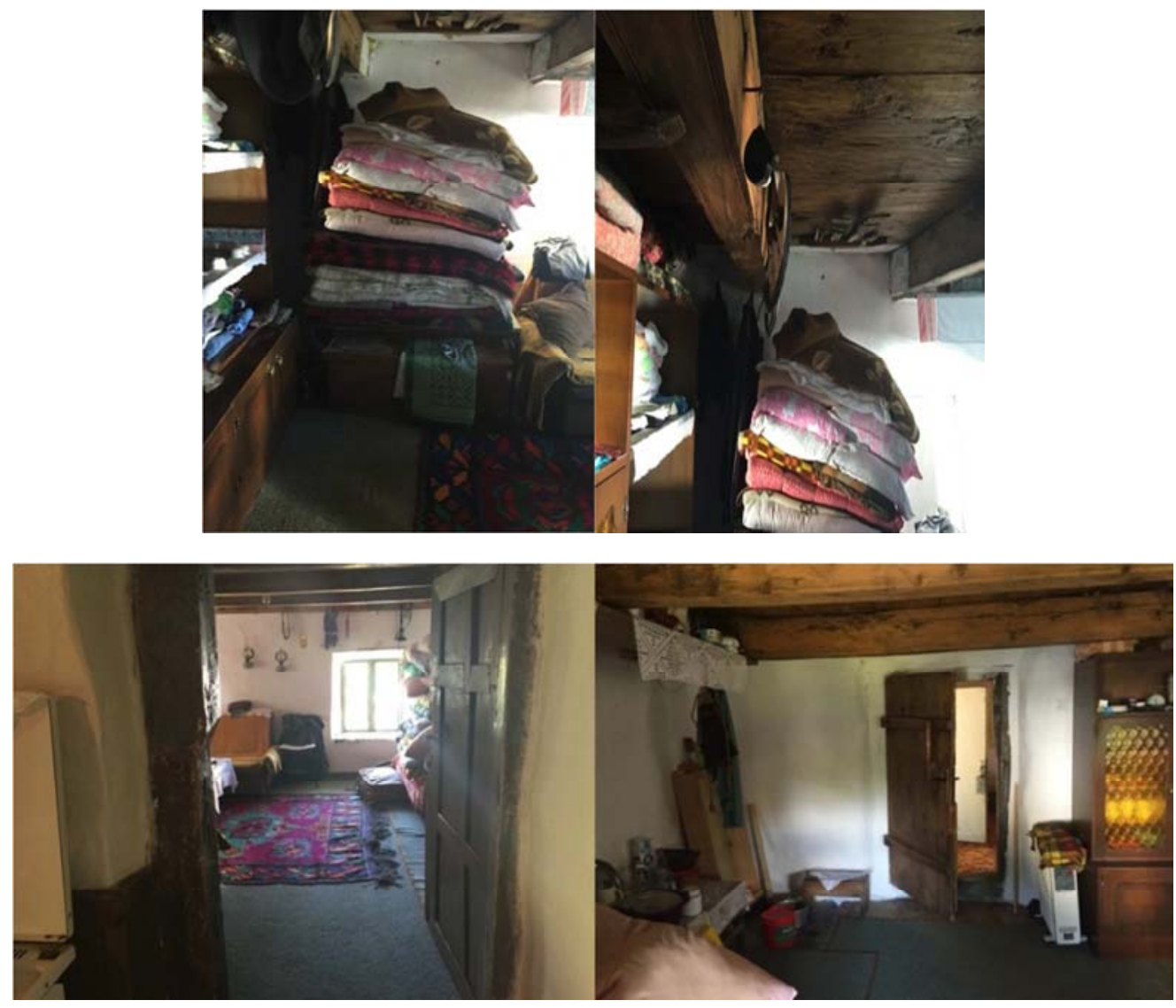

Figure 7. Room in the Cukas family house.

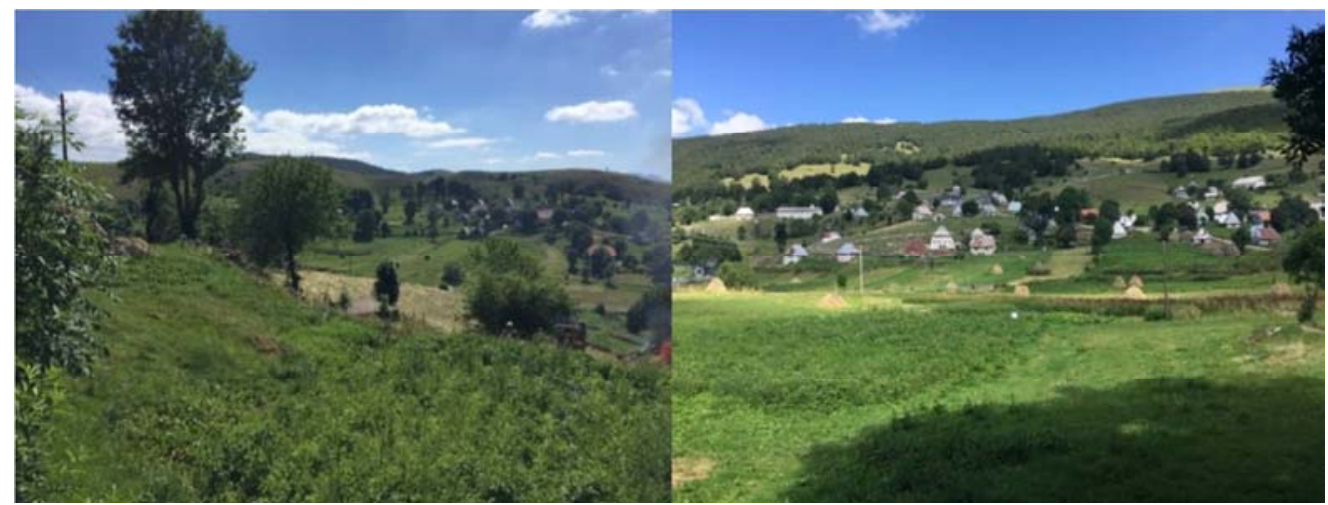

Figure 8. Views of the Cuhovici village from the Tresnjo family house (left) and from the Cukas family house (right). 


\section{Construction and Materialization}

The main building materials used to build the Tresnjo and Cukas houses are stone, wood and earth. All the walls (about $80 \mathrm{~cm}$ thick) are made of stone. The walls are roughly plastered, inside and out, and painted with lime. The ceiling structures are made of wooden beams (placed at a distance of about $80 \mathrm{~cm}$ ), on which, on their upper side, a floor of thick boards is placed, which is also a support for the space below (Figures 9, 11, 12, 15). The roof structure is made of wood as well as shingle cover (in the original house design) and doors and windows.

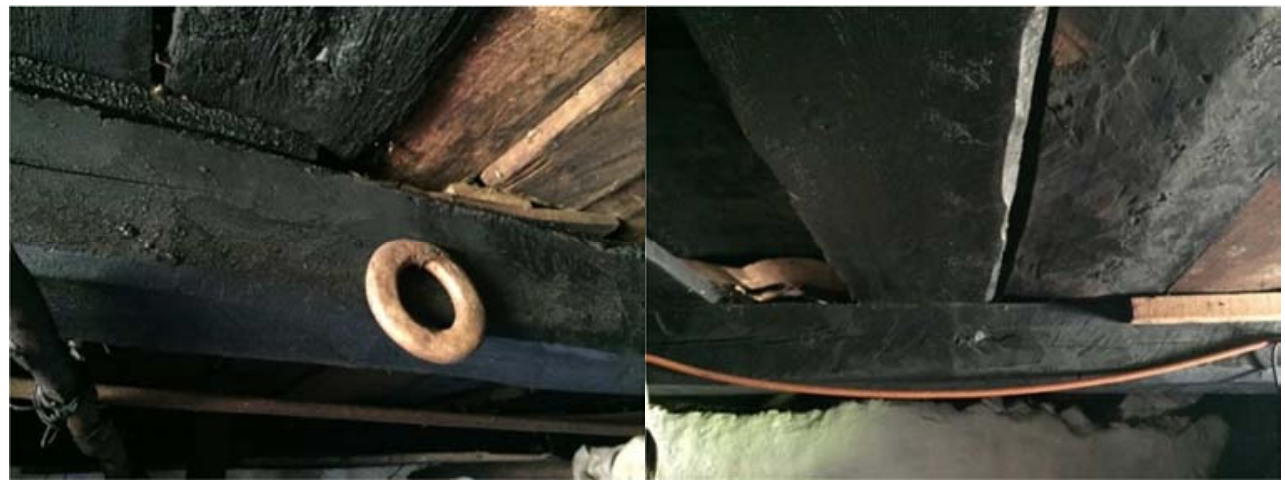

Figure 9. Beams and part of the floor in the "kuca" area (Tresnjo family house).

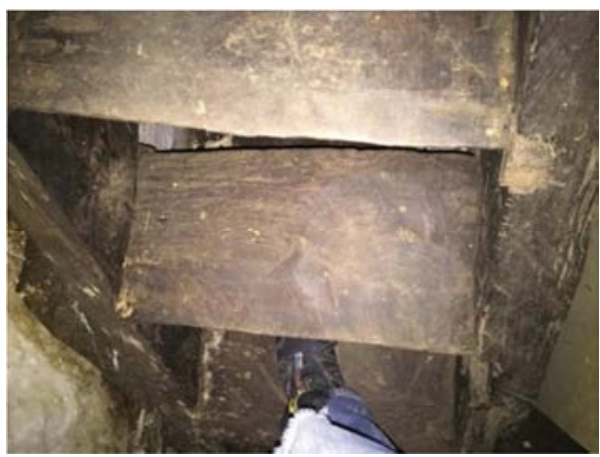

Figure 10. Staircase connecting the space of the "kuca" and the chardak (Tresnjo family house).
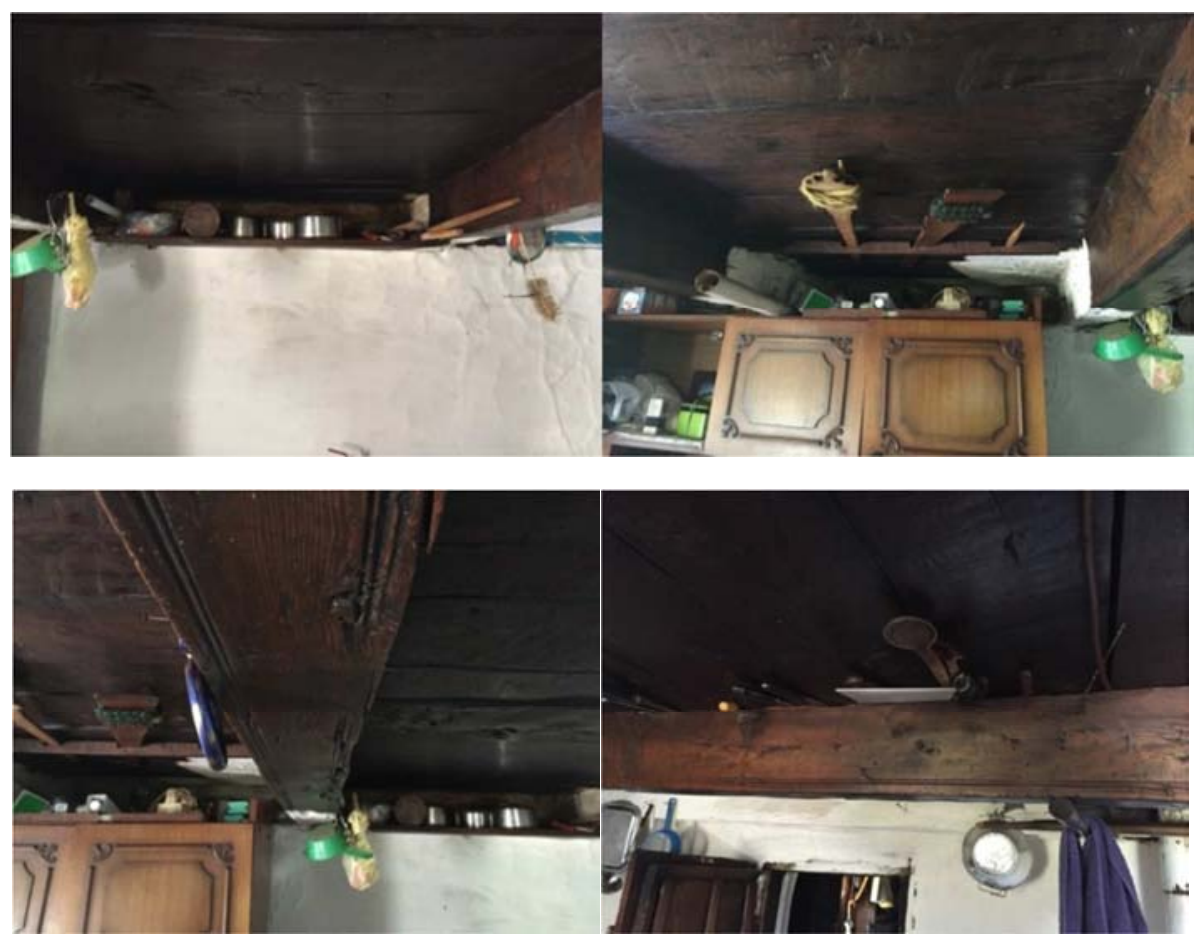


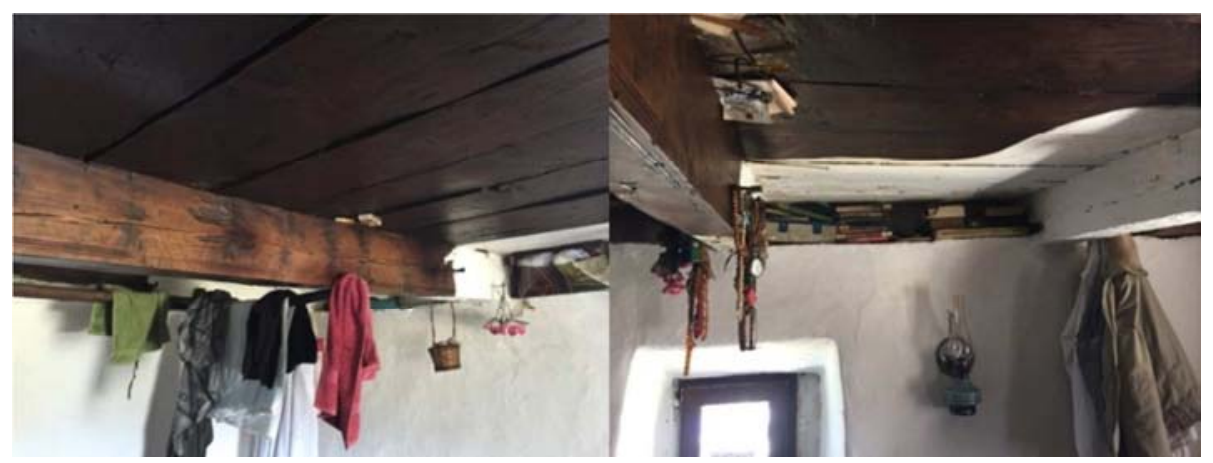

Figure 11. Wooden ceiling ("shishe") in room (Tresnjo family house).

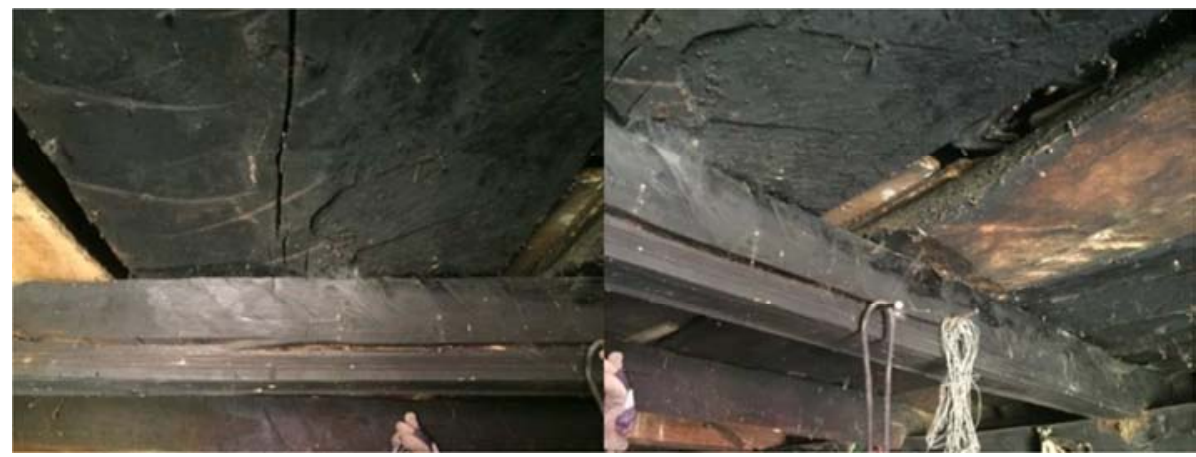

Figure 12. Ceiling "kuca" - attic in the Cukas family house.

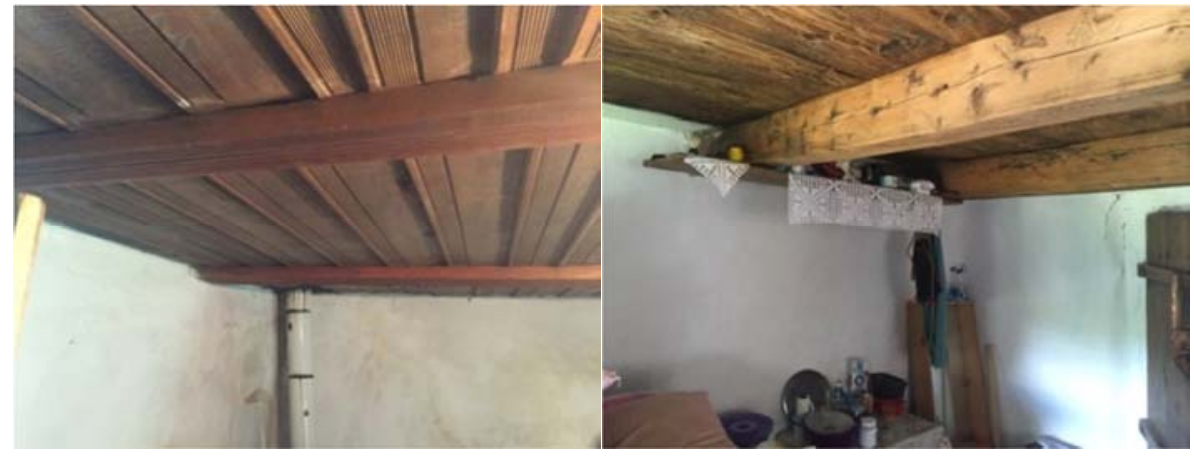

Figure 13. Wooden ceiling in the space of the "kuca" (today living room) in the Cukas family house.

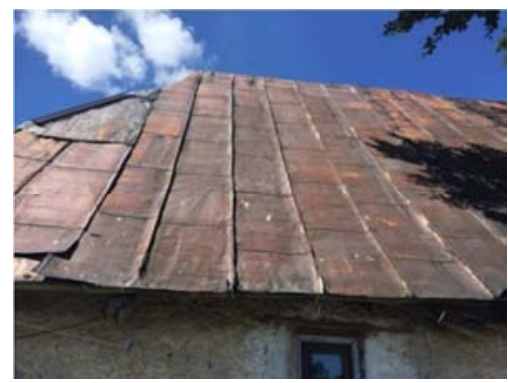

Figure 14. Retrofitted tin and existing shingle cover: effective protection against extreme weathering.

\section{Surface Treatment}

As already mentioned, the inner and outer surfaces of the stone walls are roughly plastered with lime mortar and finally covered with lime milk. The ceilings are made of wood finely trimmed boards, partially trimmed with edge profiles. Formerly the ceiling structure of the room-ceiling had no sand charge and at that time only the ceiling beams were decorated with edge profiles. The floors of the attic were finely carved on their underside (like the ceiling in the room). The joists in the rooms were a special kind of pantry, where some usable items were being "hitched", while in some places special types of shelves ("rafa") were arranged (Figures 11, 15).

In the house of the Tresnjo family, the ground-to-ceiling connection is made of massive, finely carved, wooden tulips that, over time, due to smoke exposure from the hearth, have become honey (Figure 10).

The floor in the living area ("kuca"), where the open hearth is located, is made of compacted earth with the addition of animal hair, as reinforcement. 

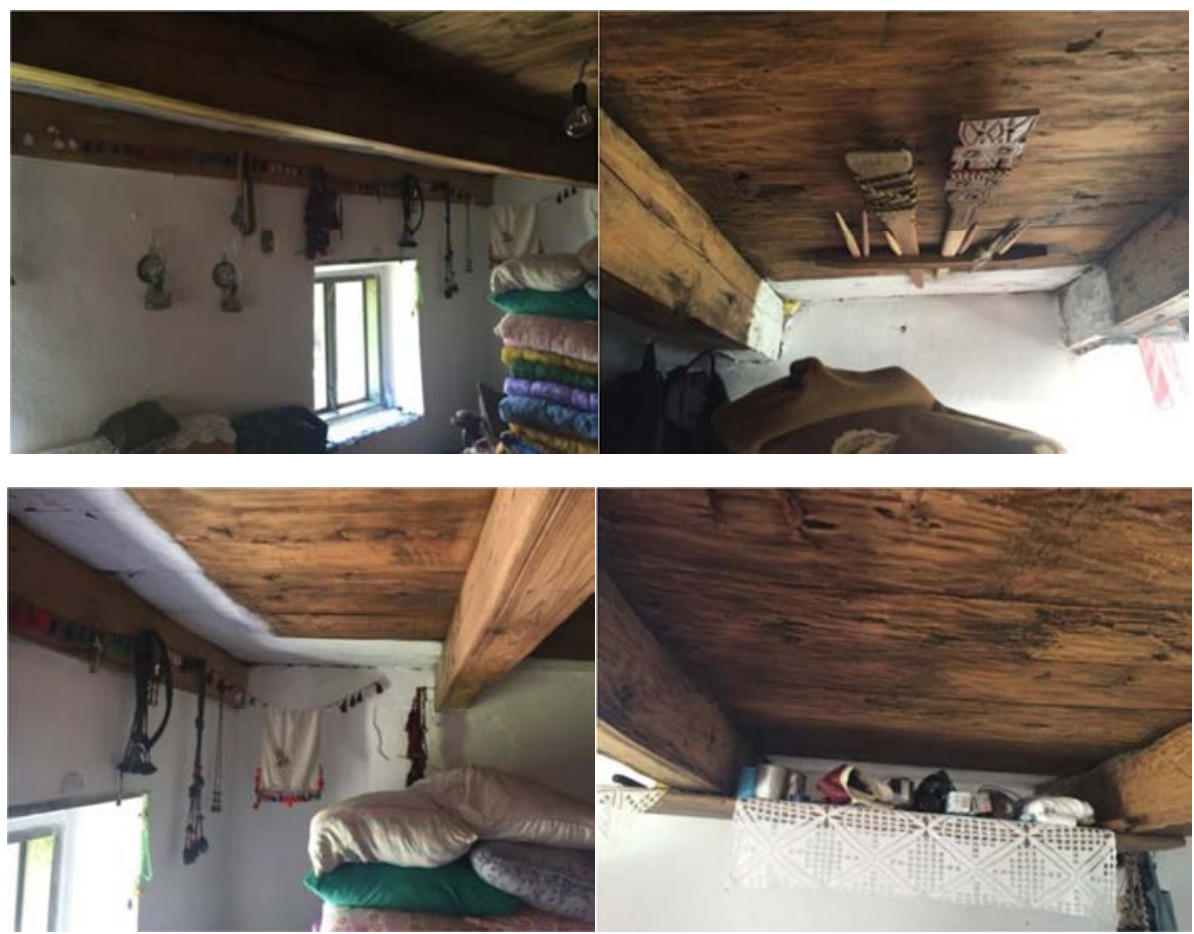

Figure 15. Wooden ceiling in the room of the Cukas family house.

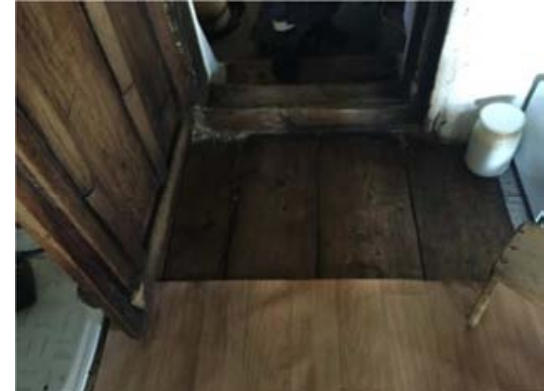

Figure 16. Wooden floor in the room of the Tresnjo family house.

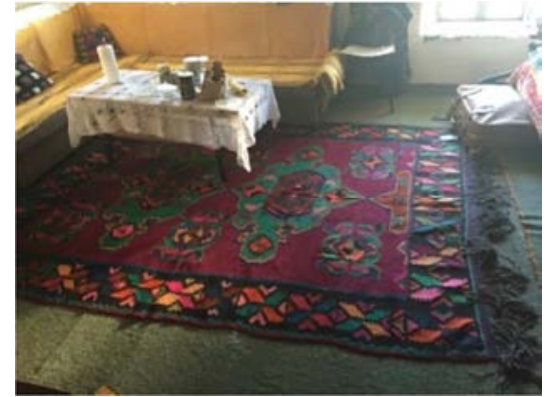

Figure 17. The floor in the room of the Ćukas family house.

\section{Doors and Windows}

The doors in the houses of the Tresnjo and Cukas families are of very simple construction: a wooden frame and sash boards interconnected by two or three wooden crossbars (Figure 18). It is interesting that the door dividing the "kuca"space and the main room contained a small glazed opening whose function was to transmit light from the "kuca" space (from an open fire) into the room. As the door was exposed to the smoke, it got a nice honey color over time (Figures 19, 20, 21).

The windows on these houses are small rectangular in size, double glazed and with several small windows, glazed with single glass (Figures22, 23).

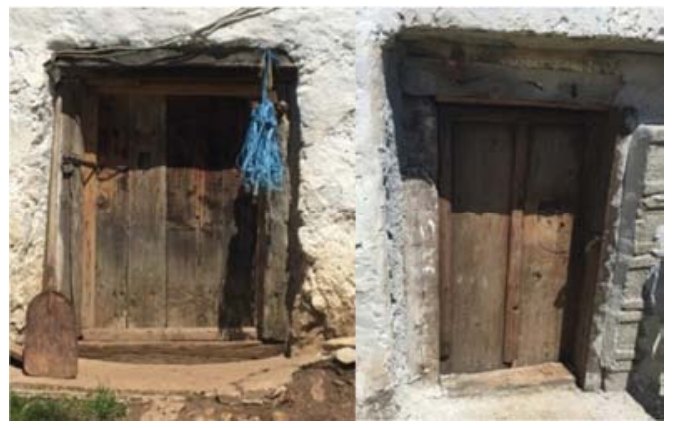

Figure 18. Doors at the basement entrance of the Tresnjo family house (left) and the Cukas family house (right).

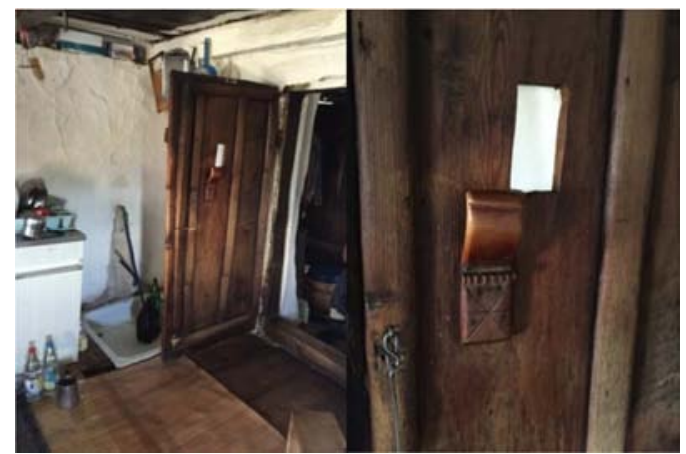

Figure 19. Doors on the room in the Tresnjo family house (Door detail "saving opening" for transmitting light from the "kuca" to the room). 


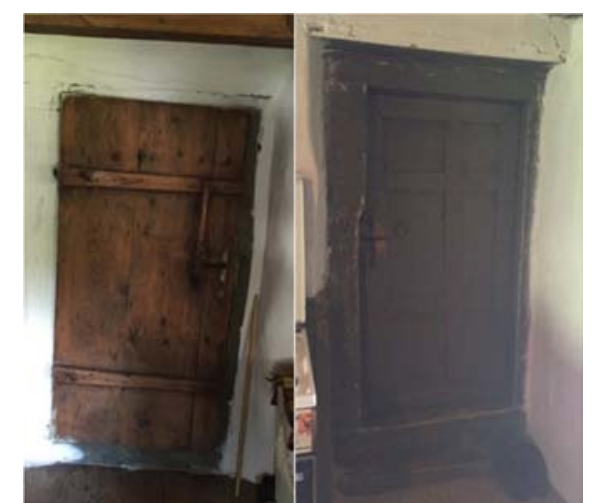

Figure 20. A door to a room in the Cukas family house.
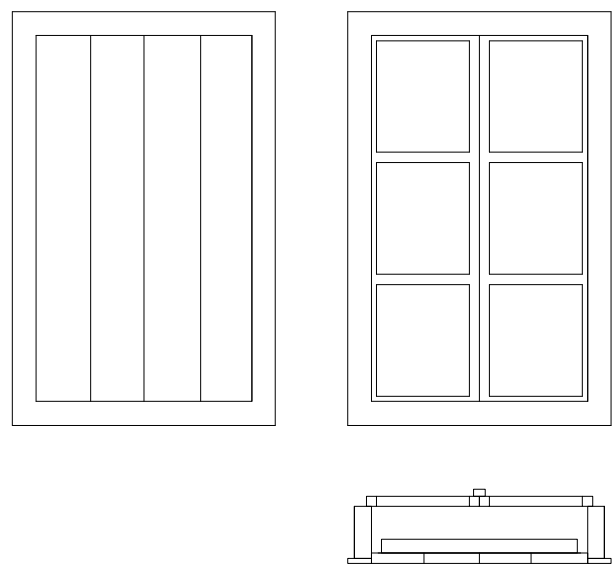

Figure 22. Window with wooden shutter (Trešnjo family house).

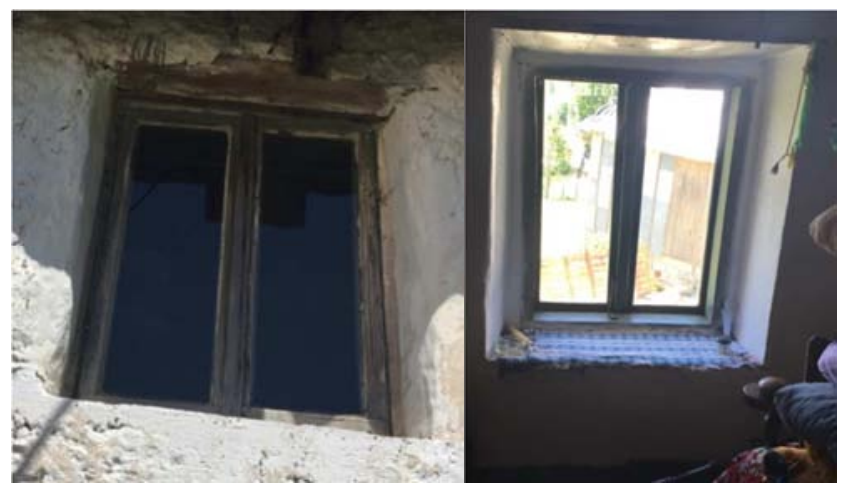

Figure 23. A window on a room in the Cukas family house.

\section{Conclusion}

The Tresnjo family house is still used today in the traditional way, where open fireplace in the space of the "kuca" plays a key role, both in the culture of housing [16] and in maintaining the house as a physical structure. The house of the Cukas family has been partially renovated: part of the open space between the "kuca"and roof space closed to provide access to the chardak space. In this house, too, a narrow space ("dimluk") is left between the narrowed space of the "kuca" and the space of the attic into which smoke comes out, from the hearth or stove to the wood (Figures 25, 26).

The House of the Cukas family shows how it can be used

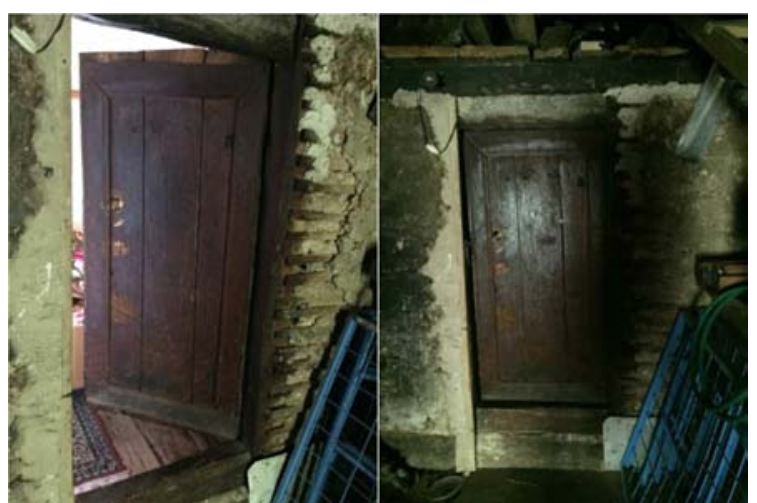

Figure 21. The door to the chardak in the Cukas family house.

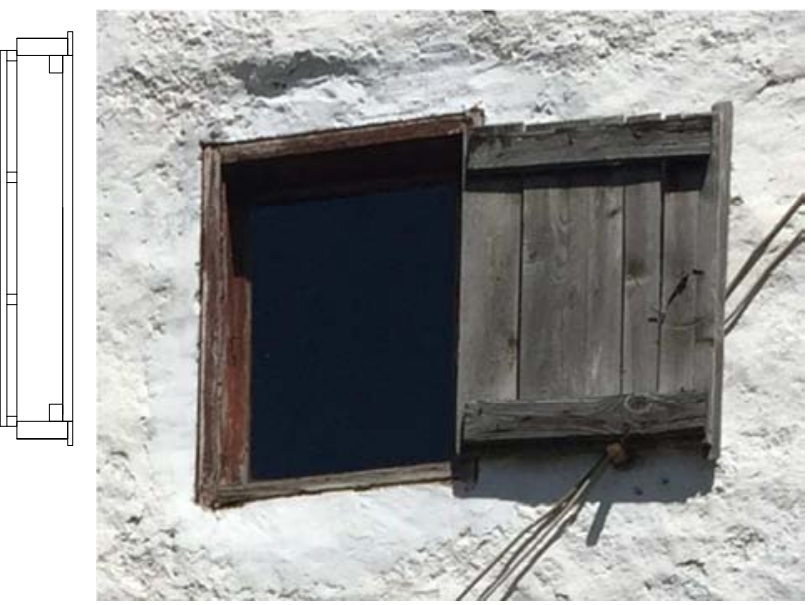

in the future for housing (during holidays or on weekends) people who, by the way, live a modern life in the city. These traditional homes for contemporary people mean their connection to their ancestors and their traditional way of life and places that enrich them with a special life energy. Examples of building new houses (similar to traditional houses) in the Umoljani village on the Bjelasnica plateau, issued to visitors "for staying in the atmosphere of a traditional village", point to other perspectives of the Bosnian house of chardaklia in the Cuhovici village.

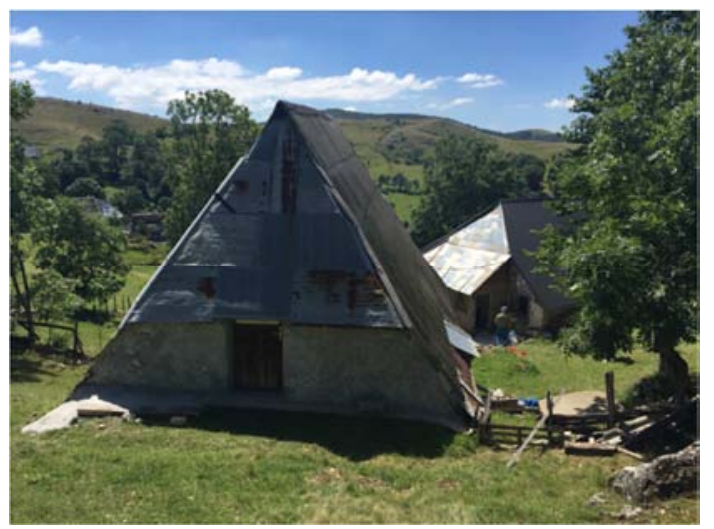

Figure 24. New entrance to the attic (attic with attic) in the Cukas family house. 


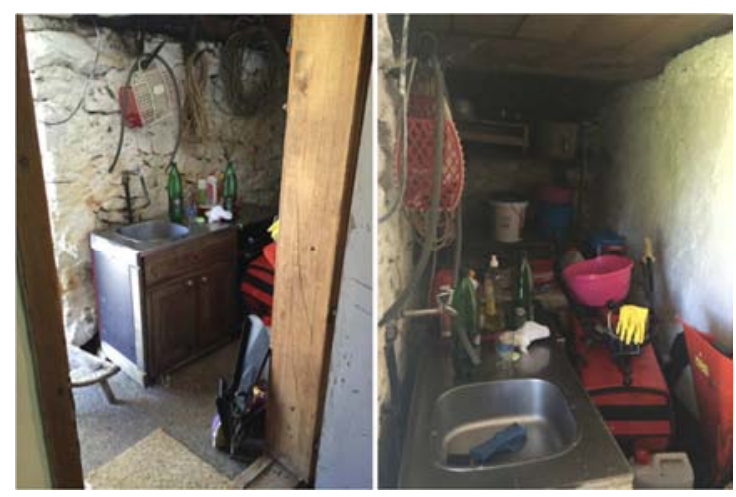

Figure 25. The area around the old open fireplace is today fenced off and converted into an entrance lot with a kitchenette (the Cukas family house).
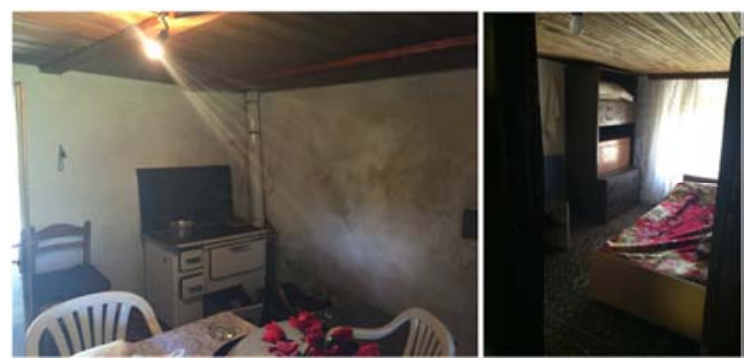

Figure 26. Remodeled space of the former "kuca" into a living room (left) and a new porch (right) in the Cukas family house.

\section{References}

[1] Hadrovic, A. (2008.), Bioclimatic Architecture, Searching for a Path to Heaven, Booksurge, LLC, North Charleston, SC, USA.

[2] Cvijić, J. (1922.), Balkansko poluostrvo i jugoslovenske zemlje, Beograd.

[3] Karanović, M. (1927.), O tipovima kuća u Bosni, Državna štamparija, Sarajevo.

[4] Soldo, Š. (1932.), Tipovi kuća i zgrada u pređašnjoj Bosni i
Hercegovini, Državna štamparija Kraljevine Jugoslavije, Beograd.

[5] Deroko, A. (1964.), Narodna arhitektura, knj. II, Naučna knjiga, Beograd.

[6] Kadić, Dr M. (1967.), Starinska seoska kuća u BiH, Veselin Masleša, Sarajevo.

[7] Hadrović, A. (2017.), Bosanska kuća čardaklija, Sarajevo, Arhitektonski fakultet u Sarajevu, Sarajevo.

[8] Hangi, A. (1906.), Život $i$ običaji muslimana u Bosni $i$ Hercegovini, Naklada Daniela A. Kajona, Sarajevo.

[9] Baylon, M. (1981), Stanovanje, Tema 6: Stan-kuća, Arhitektonski fakultet Univerziteta u Beogradu, PDS, Kurs „Stanovanje“, Beograd.

[10] Hadrovic, A. (2007.), Defining Architecrural Space on the Model of the Oriental Style City House in Bosnia and Herzegovina, Serbia, Montenegro, Kosovo and Macedonia, Booksurge, LLC, North Charleston, SC, USA.

[11] Alić, H. S. (1976.), Arapsko-islamska filozofija; definicija i značaj u istoriji, Orijentalni institut u Sarajevu, POF XXIV/ 1974., Sarajevo.

[12] Hadrovic, A. (2009.), Hadre, The Evolution of Bioclimatic Architecture, Booksurge, LLC, North Charleston, SC, USA.

[13] Hadrovic, A. (2010.), Research study on Architecture and Overview of the Architect's Experience), Sarajevo, Acta Architectonica et Urbanistica, Faculty of Architecture University of Sarajevo.

[14] Hadrovic, A. (2010.), Architectural Physixs), Sarajevo, Acta Architectonica et Urbanistica, Faculty of Architecture University of Sarajevo.

[15] Vitruvius, P. M. (1958.), De arhitectura libri decem, Svjetlost, Sarajevo.

[16] Hadrovic, A. (2014.), Water and man in autoshthonous symbiosis in Bosnia and Herzegovina, Avicena, Sarajevo.

[17] All Figures (drawings and photos), except Fugures 1, were made by the Author (2016). 